\title{
BIBLIOGRAFI SEJARAH PAKAIAN DI INDONESIA PADA MASA PEMERINTAHAN HINDIA BELANDA
}

\author{
Ayu Septiani \\ Departemen Sejaran dan Filologi Fakultas Ilmu Budaya, Universitas Padjadjaran, Sumedang, Indonesia \\ ayu.septiani@unpad.ac.id
}

\begin{abstract}
ABSTRAK
Sejarah pakaian saat ini mulai diminati. Hal itu disebabkan oleh munculnya trend baru penggunaan masker karena terjadinya pandemik global yang masih berlangsung hingga kini yaitu Covid-19. Untuk menelusuri perkembangan pakaian di Indonesia pada masa lalu tentu diperlukan pengkajian kepustakaan atau bibliografi. Tentu saja, pada masa lalu sudah terdapat publikasi-publikasi yang diterbitkan terkait perkembangan pakaian seperti buku, jurnal, majalah, surat kabar yang dapat diakses untuk digunakan dalam merekonstruksi sejarah pakaian. Diawali dengan memaparkan konteks sejarah pada masa Pemerintahan Hindia Belanda, maka tujuan penelitian ini yaitu menginventarisasi dan mengidentifikasi sumber-sumber informasi terakait sejarah pakaian. Adapun metode yang digunakan adalah metode sejarah. Hasil penelitian ini menunjukkan bahwa sumber-sumber terkait sejarah pakaian sangat banyak dan beragam. Oleh karenanya harus dimanfaatkan dengan baik dan efektif sehingga dinamika yang terjadi dalam bidang sejarah budaya terlihat lebih lengkap dan komprehensif. Selain itu pula, diharapkan penelitian menganai bibliografi sejarah pakaian dapat membantu para peneliti khususnya peneliti sejarah yang tertarik mengkaji sejarah pakaian di Indonesia.
\end{abstract}

\section{ABSTRACT}

Clothing history is currently starting to be in demand. This is due to the emergency of a new trend in the use of masks and changes in the time of wearing clothes due to the global pandemic that is still ongoing today, namely Covid-19. To trace the development of clothes in Indonesia in the past, of course, it is necessary to study the literature or bibliography. Of course, in the past there have been publications related to clothes developments such as books, journals, magazines, newspapers that can be accessed for use in reconstructing the history of clothes. Beginning by describing the historical context during Dutch East Indies government, the purpose of this research is to take an inventory and identify a number of publications related to the history of clothes. The method used is the historical method. The results of this study indicate that the publications related to the history of clothes are numerous and varied. Therefore, it must be used properly and effectively so that the dynamics that occur in the clothes sector look more complete and comprehensive. In addition, it is hoped that research on the bibliography of clothes history can help historical researchers who are interested in studying the history of clothes in Indonesia.

\section{ARTIKEL INFO}

Diterima: 26 November 2021

Direvisi: 14 Desember 2021

Disetujui: 24 Desember 2021

\section{KATA KUNCI}

Bibliografi

Sejarah Pakaian

Hindia-Belanda

\section{KEYWORDS}

Bibliography Clothing History Netherlands-Indie 


\section{Pendahuluan}

Pakaian merupakan pelindung tubuh, lebih dari itu, pakaian juga dapat menunjukkan identitas seseorang atau sekelompok individu. Misalnya, jika seorang individu menggunakan jas atau blazer, kemeja, dan celana pantalon, maka otomatis orang berpikir bahwa individu tersebut bekerja kantoran. Contoh lainnya adalah jilbab yang identic dengan muslimah. Jilbab menjadi penanda identitas bahwa perempuan tersebut beragama Islam.

Pada masa pandemik Covid-19 dimana pemerintah menyosialisasikan penggunaan masker sebagai satu di antara beberapa cara pencegahan penularan virus korona, menjadikan masker sebagai trend baru dalam gaya berpakaian. Sebelum pandemik, masker hanya dikenal dalam dunia medis yang dinamakan masker medis penggunanya pun kalangan terbatas yaitu mereka yang bergerak dalam bidang kesehatan seperti dokter, perawat, dan tenaga kesehatan lainnya, selain itu juga, masker hanya digunakan oleh para pengendara sepeda motor untuk melindungi mereka dari bahaya polusi udara.

Pada masa pandemik Covid-19 hingga kini. Muncul beragam jenis masker dengan berbagai motif dan bahan. Selain itu pula muncul inovasi aksesoris pelengkap masker seperti connectori dan strap mask. Berangkat dari fenomena kekinian tersebut menurut hemat penulis pakaian menjadi unsur yang penting dan perlu dikaji lebih dalam. Pun ketika pada masa lalu saat Indonesia masih dalam penguasaan Pemerintah Hindia Belanda, bagaimana pengaruh perempuan Eropa di Hindia Belanda memengaruhi pemikiran perempuan bumiputra yang terikat kuat oleh budaya patriarki yang membatasi ruang gerak mereka. Paradigma bahwa perempuan hanya mengurus urusan dapur, sumur, dan kasur sangat melekat kuat sehingga para perempuan bumiputra pada masa tunduk dan patuh pada sistem patriarki.

Tulisan ini merupakan ulasan ilmiah yang memfokuskan pada penjelasan tentang sumbersumber terkait sejarah pakaian. Menurut hemat penulis, kajian terdahulu yang secara khusus membahas sumber-sumber tentang sejarah pakaian belum ada. Jikalaupun ada, dalam bentuk katalog yang biasanya ditemui di perpustakaanperpustakaan daerah seperti Perpustakaan Provinsi Jawa Barat dan perpustakaan negara seperti Perpustkaan Nasional Republik Indonesia, serta perpustakaan lembaga negara seperti Arsip Nasional Republik Indonesia.
Tulisan yang membahas tentang bibliografi sumber-sumber sejarah penulis temukan melalui situs internet dari Jurnal Paramita Vol. 22 No. 2, Juli 2012. Artikel tersebut berjudul "Bibliografi Sejarah Kesehatan Pada Masa Hindia Belanda" karya Mumuh Muhsin Zakaria. Dalam artikel tersebut dipaparkan mengenai publikasipublikasi yang terbit pada masa kolonial baik berupa buku, jurnal, surat kabar yang dapat diakses untuk mengetahui dan merekonstruksi Sejarah Kesehatan di Nusantara. Sementara itu karya lainnya memfokuskan pada sejarah pakaian pada suatu masa tertentu yang justru bukan menjadi objek pembahasan dalam artikel ini.

Oleh karena itu, menurut hemat penulis dapatlah dikatakan bahwa artikel berjudul "Bibliografi Sejarah Pakaian di Indonesia pada Masa Hindia Belanda" ini merupakan artikel pertama yang membahas mengenai sumbersumber terkait sejarah pakaian pada Masa Hindia Belanda.

Alasan penulis mengangkat judul tersebut yaitu untuk memberikan informasi kepada pembaca baik yang memiliki latar belakang Pendidikan Sejarah seperti mahasiswa sejarah dari berbagai jenjang pendidikan, guru dan dosen maupun masyarakat yang tidak memiliki latar belakang pendidikan sejarah seperti pemerhati, pegiat, dan penulis buku atau novel sejarah. Selain itu, pakaian merupakan tema yang menarik karena memiliki perjalanan sejarah yang relative panjang dan menyentuh relasi gender antara laki-laki dan perempuan. Fokus pembahasan dalam artikel ini yaitu sumbersumber baik primer maupun sekunder tentang sejarah pakaian.

Dengan demikian, tujuan penelitian ini yaitu menginventarisasi dan mengidentifikasi sumbersumber informasi terkait sejarah pakaian. Adapun landasan konsep yang digunakan yaitu konsep identifikasi dan inventarisasi. Menurut Kamus Besar Bahasa Indonesia (2008: 538 \& 562), identifikasi adalah perbuatan menetapkan identitas seseorang, benda, dan sebagainya. Sementara itu inventarisasi adalah pencatatan atau pengumpulan data.

Dalam kaitannya dengan artikel ini, penulis mengidentifikasi sumber-sumber sekunder seperti jurnal ilmiah dan buku yang diakses melalui internet. Setidaknya terdapat satu judul buku yang penulis identifikasi dan penulis jadikan sebagai referensi utama dalam penulisan artikel ini yaitu buku berjudul "Outward Appearance; Trends, Identitas, dan Kepentingan." Buku tersebut merupakan kumpulan tulisan dari 
beberapa penulis yang memiliki ketertarikan dalam hal peran dan arti pakaian dalam pergaulan sosial. Buku tersebut ditulis oleh 11 penulis dengan judul yang berbeda-beda dan dieditori oleh Henk Schulte Nordholt. Namun, dari 11 judul dalam buku tersebut, hanya tiga tulisan yang penulis ulas dalam artikel ini karena aspek temporal dalam tiga tulisan tersebut sesuai dengan pembahasan artikel ini yaitu pada masa Pemerintahan Hindia Belanda. Selain buku kumpulan tulisan tersebut, penulis juga mengulas tentang sumber primer seperti buku, arsip, surat kabar, dan majalah yang diterbitkan pada masa Pemerintahan Hindia Belanda.

\section{Metode Penelitian}

Metode yang digunakan untuk menyusun artikel ini adalah metode studi pustaka seperti buku dan jurnal tercetak serta sumber pustaka yang diperoleh secara online seperti e-journal, $e$ book, dan e-archive.

Penyusunan artikel ini dilakukan melalui tiga tahap, pertama mencari judul artikel. Kedua, melakukan penelusuran sumber secara offline dan online. Ketiga, penyusunan naskah. Dalam proses mencari judul artikel, penulis melakukan studi pustaka secara offline di perpustkaan pribadi penulis karena penulis memiliki minat pada bidang sejarah khususnya sejarah pakaian. Selain itu, tema tentang budaya material khususnya pakaian sedang diminati terutama ketika masa pandemik terjadi, hingga kini inovasi dalam bidang pakaian semakin berkembang dengan adanya penggunaan masker sebagai satu di antara cara pencegahan penularan virus Covid-19. Maka, tercetuslah judul artikel "Bibliografi Sejarah Pakaian di Indonesia pada Masa Pemerintahan Hindia Belanda."

Penelusuran sumber mula-mula dilakukan secara offline dengan memanfaatkan koleksi kepustakaan milik pribadi penulis. Selanjutnya, penulis melakukan penelusuran secara online dengan memanfaatkan situs www.perpustakaan.go.id,

https://sinta.kemendikbud.go.ig/ dan https://www.delpher.nl/. Ketiga situs tersebut merupakan situs milik lembaga negara yang kredibel. Adapun tahap ketiga yaitu penyusunan naskah berjudul "Bibliografi Sejarah Pakaian di Indonesia pada Masa Pemerintahan Hindia Belanda."

Selain sumber-sumber kepustkaan sebagaimana yang telah dijelaskan di atas, penulis juga menyinggung beberapa sumber seperti surat kabar dan majalah yang menjadi koleksi Perpustakaan Nasional Republik
Indonesia yang terbit pada masa Pemerintahan Hindia Belanda dan dapat digunakan sebagai sumber primer bagi penulisan sejarah pakaian.

\section{Hasil dan Pembahasan}

\section{Indonesia pada Masa Pemerintahan Hindia Belanda}

Setelah VOC resmi dibubarkan pada 1799, Hindia Belanda mengalami masa transisi. Penguasaan terhadap Hindia Belanda berpindah ke tangan Pemerintah Belanda. Peristiwa penting berkait dengan kedudukan bupati dan sejarah pakaian adalah pada masa Herman Willem Daendels menjadi Gubernur Jenderal yang memerintah dari tahun 1808-1811. Daendels secara drastic menurunkan kedudukan bupati. Bupati ditempatkan sebagai pegawai pemerintah yang digaji dan berada di bawah perinta prefek. Hal ini mempengaruhi gelar bupati, baik gelar kebangsawanan maupun gelar jabatan (Hardjasaputra, 1985: 42).

Kemudian, pada masa Raffpes (1810-1811), bupati menjabat sebagai polisi yang mengawasi keamanan daerahnya. Hal ini juga tentunya disimbolkan dalam pangkat yang digunakan. Barulah pada masa Van der Capellen, kedudukan bupati perlahan-lahan dinaikkan kembali. Bupati diberi tanda kepangkatan. Seiring dengan berjalannya waktu, prinsip pewarisan jabatan diteguhkan kembali dan bupati diberi tanda jasa oleh Pemerintah Hindia Belanda bagi mereka yang memiliki hubungan kerja sama yang baik dengan pemerintah (Hardjasaputra, 1985: 49).

Pada abad ke-19 pakaian dan kekuasaan sangat erat kaitannya. Oleh karenanya, dalam tulisan ini, penulis mengungkapkan bahwa posisi bupati sebagai pegawai pemerintah dan pemimpin tradisional disimbolkan dalam pakaian yang digunakan oleh mereka, pakaian yang digunakan bupati mencakup atribut yang melambangkan gelar kebangsawanan dan gelar jabatan yang dimilikinya. Seiring dengan perubahan sistem politik dalam struktur Pemerintah Hindia Belanda pun memengaruhi posisi dan kedudukan bupati. Hal tersebut kemudian berdampak pada penggunaan atribut dan tanda kebesaran bupati dalam pakaian mereka.

Pada abad ke-19, Pemerintah Hindia Belanda mempertahankan ciri-ciri kebangsawanan bupati bahkan diatur secara tertib dengan peraturan dan undang-undang. Hal tersebut bertujuan untuk menjaga dan melestarikan kewibawaan golongan bupati sebagai aparatur pemerintah dan sebagai pemimpin tradisional. 
Ketika pada akhir abad ke-19 hingga awal abad ke-20 muncul golongan intelektual dan menggeser kedudukan bupati, pemerintah Hindia Belanda tetap melestarikan ciri-ciri kebangsawanan bupati dengan memberikan berbagai tanda jasa atas kerja sama yang baik yang dilakukan oleh para bupati.

\section{Kedudukan Sumber dalam Penelitian Sejarah}

Ilmu Sejarah merupakan ilmu yang bersifat empiris. Artinya, penelitian terkait bidang ilmu sejarah harus menggunakan sumber. Sumbersumber dalam ilmu sejarah dapat diklasifikasikan ke dalam beberapa kategori. Menurut Gottschalk (1975: 35-36), sumber sejarah dikategorikan dalam tiga golongan besar yaitu sumber tertulis, sumber lisan, dan sumber benda. Sementara itu, Renier mengelompokkannya dalam dua kelompok besar yaitu immaterial dan material. Terdapat dua klasifikasi sumber material menurut Renier yaitu tertulis dan tidak tertulis. Adapun sumber immaterial menurut Renier yaitu semua jejak yang tidak terlihat dan masih hidup dalam masyarakat seperti lembaga, adat-istiadat, ajaran-ajaran, etika, legenda, tradisi dan kepercayaan (Renier, 1997: 104).

Klasifikasi sumber sejarah menurut Garraghan (1957: 98-99; 107; 122-123) terbagi menjadi dua yaitu berdasarkan bentuknya dan asal usulnya. Sumber sejarah berdasarkan bentuknya sama seperti pendapat Gottschalk terdiri dari sumber tertulis, sumber lisan, dan sumber benda. Sedangkan berdasarkan asal usulnya, sumber sejarah terdiri dari sumber primer, sekunder, dan tersier. Dalam bukunya berjudul "A Guide to Historical Method" (1957: 107), Garraghan menjelaskan secara lebih rinci tentang sumber primer, sekunder, dan tersier.

Sumber primer yaitu sumber atau penulis menyaksikan, mendengar, dan mengalami sendiri peristiwa yang dituliskan dalam sumber tersebut. Sumber primer terbagi dua yaitu strictly primary sources (sumber primer kuat) yakni sumber yang berasal langsung dari saksi mata peristiwa dan less strictly primary sources (sumber primer kurang kuat) yakni sumber yang berasal dari zaman terjadinya suatu peristiwa tetapi tidak memiliki hubungan langsung dengan peristiwa tersebut. Sementara itu, sumber sekunder merupakan sumber atau penulis sumber hanya mendengar peristiwa itu dari orang lain. Sedangkan sumber tersier merupakan konsep khusus dan tidak berlaku umum, contohnya skripsi, tesis, disertasi, dan karya ilmiah lain. Dalam kajian sejarah sumber tersier acapkali disamakan dengan sumber sekunder.
Artinya konsep sumber yang berlaku untuk kajian sejarah hanya dua yaitu primer dan sekunder. Para peneliti sejarah biasanya berangkat dari sumber sekunder yang digunakan sebagai "pintu masuk" untuk menemukan sumber-sumber primer baik yang kuat maupun kurang kuat.

Dengan demikian, kedudukan sumber bagi penelitian sejarah sangan penting dan utama. Terlebih jika berkaitan dengan tema-tema sejarah material, seperti pakaian. Sumber yang diulas dalam artikel ini berbentuk buku yang termasuk dalam sumber sekunder. Selain itu pula disinggung arsip yang termasuk dalam sumber primer kuat. Sementara itu, diulas pula Koran dan majalah yang terbit pada masa Pemerintahan Hindia Belanda yang termasuk dalam kategori sumber sezaman atau sumber primer kurang kuat (less strictly primary sources).

\section{Sumber-Sumber Berkait Penulisan Sejarah Pakaian}

Sumber pertama yang penulis temukan mengenai sejarah pakaian yaitu buku kumpulan tulisan yang dieditori oleh Henk Schulte Nordholt berjudul "Outward Appearance; Trend, Identitas, dan Kepentingan." Dalam buku tersebut terdapat beberapa artikel yang dapat dijadikan sebagai sumber sekunder untuk penulisan sejarah pakaian.

Dalam buku kumpulan tulisan tersebut terdapat tiga tulisan yang membahas tentang pakaian pada masa Pemerintahan Hindia Belanda. Pertama, artikel karya Jean Gelman Taylor berjudul "Kostum dan Gender di Jawa Kolonial tahun 1800-1940."

Dalam tulisannya, Gelman memaparkan bagaimana pakaian dapat memengaruhi relasi gender. Negara colonial telah mendorong munculnya perbedaan penampilan antara lakilaki dan perempuan. Hal tersebut menunjukkan bahwa proses penaklukan oleh Pemerintah Hindia Belanda disertai dengan sejarah sosial tentang perubahan aturan perpakaian (Nordholt, 1997: 5).

Kedua, artikel karya Rudolf Mrazek berjudul Kenecisan Indonesia; Politik Pakaian pada akhir Masa Kolonial 1893:1942. Dalam tulisannya, Mrazek menceritakan tentang para nyonya Hindia Belanda yang menampilkan koleksi boneka kepada Ratu Belanda berjumlah sekitar 150 buah. Beberapa boneka mengenakan pakaian serba putih, dan lainnya menggambarkan hierariki kepegawaian bumiputra yang dikelompokkan berdasarkan regionalnya. Contohnya, satu set boneka dari 
Preanger dan Jawa Timur memperlihatkan adipati, raden ajoe adipati, patih, mantra, djoeroetoelis, sampai 35 tingkat jabatan ke bawah termasuk orang tani dan njai tani. Selain itu terdapat pula boneka yang menggambarkan profesi-profesi bumiputra, seperti jaksa dan istirnya, subkolektor pajak, pengawas pengairan, guru, dokter, dan petugas yang berwenang memberikan vaksinasi (Nordholt, 1997: 169170).

Adapun artikel ketiga dalam buku Nordholt (1997) berjudul "Pakaian Musim Panas dan Makanan Kaleng; Perempuan Eropa dan Gaya Hidup Barat di Hindia tahun 1990-1942," yang ditulis oleh Elsbeth Locher-Scholten.

Elsbeth menganalisis sikap perempuan berdasarkan alam kultural perempuan yaitu mode dan makanan. Menurutnya, pakaian dapat dilihat sebagai ungkapan pembeda sosial seperti usia, kelompok, dan gender, serta sebagai indicator norma dan nilai. Elsbeth memaparkan tentang pakaian yang dimiliki oleh para perempuan Eropa, meliputi blus, rok, dan gaun. Semua pakaian tersebut dibuat dari bahan katun dan linen. Para perempuan Eropa tersebut juga kerap menggunakan kaca mata pelindung debu dan topi. Hal tersebut tentu saja disesuaikan dengan wilayah Hindia Belanda yang beriklim tropis (Nordholts, 1997: 223, 234-235).

Dalam stratfikasi masyarakat Hindia Belanda saat itu. Bangsa Eropa menempati stratifikasi paling atas, posisi kedua ditempati oleh Timur Asing, dan ketiga oleh bumiputera. Pakaian yang dikenakan oleh perempuan Eropa yang sudah tinggal di Hindia Belanda sebelum awal abad ke-20 adalah kebaya putih dan kain jarik atau sarung motif batik, dalam hal ini bumiputera memengaruhi penampilan orang Eropa. Namun, ketika gaun-gaun pendek khas musim panas yang dibuat dari linen dan katun muncul pada awal abad ke-20, kebaya dan sarung mulai ditinggalkan. Para perempuan Eropa merasa nyaman menggunakan gaun pendek yang modis karena menjamin kebebasan bergerak dibandingkan dengan menggunakan kebaya dan sarung. Selain itu alasan lainnya yang diungkapkan oleh Elsbeth adalah adanya kekhawatiran dari para perempuan Eropa untuk 'menjadi bumiputera' karena sifat asli dari kebaya (Nordholt, 1997: 237). Pada masa itu orang Eropa bersifat rasis ketika memandang bumiputra. Dalam pandangan orang Eropa kala itu, bumiputra adalah kelompok masyarakat kelas bawah yang terbelakang, miskin, berkulit gelap dan tidak berpendidikan.
Berikutnya adalah arsip. Terdapat beberapa arsip yang diulas dalam tulisan ini, pertama Staatsblad tahun 1820 No. 22 tentang Resolusi dari Gubernur Jenderal dalam Dewan tanggal 9 Mei 1820 No. 6, dimana dikukuhkan menjadi suatu peraturan mengenai kewajiban dan tugas, pangkat dan gelar para bupati di Pulau Jawa. Dalam Staatsblad tersebut dijelaskan mengenai pangkat kehormatan militer. Bupati dengan gelar raden atau kyai adipati mendapat kehormatan pangkat militer Letnan Kolonel, bupati bergelar kyai tumenggung mendapat kehormatan pangkat militer Mayor, dan bupati bergelar mas ngabehi mendapat kehormatan pangkat militer kapten.

Kedua, Reglement op de Verplichtingen, Titles en Rangen der Regenten op het Eiland Java (Peraturan tentang kewajiban-kewajiban, gelargelar, dan pangkat-pangkat para bupati di Pulau Jawa) peraturan ini diperkirakan dikeluarkan antara tahum 1925-1930. Dalam peraturan itu disebutkan bahwa para bupati sebagai orang nomor satu di kabupaten diperlakukan sebagai "saudara muda" residen dan harus diikutsertakan dalam musyawarah urusan pemerintahan.

Ketiga, Staatsblad tanggal 2 April tahun 1870 no. 9 tentang pakaian dinas pegawai pribumi. Dalam Staatsblad tersebut, pemerintah Hindia Belanda menetapkan jenis pakaian kaum lakilaki dan cara serta waktu menggunakannya. Peraturan ini menetapkan pakaian dinas yang dipakai pada kesempatan resmi, seperti pada waktu pelantikan suatu jabatan, pertemuan resmi dengan pejabat Belanda, dan pesta perayaan yang berkaitan dengan acara dinas. Selain itu, ditetapkan pula pakaian dinas bila akan melakukan perjalanan yang disebut pakaian keprajuritan. Peraturan cara berpakaian ini diberlakukan untuk semua kepala dan para pegawai pribumi di Jawa dan Madura. Sementara itu, pakaian untuk istri bupati tidak diatur secara spesifik. Mereka biasanya menggunakan kebaya dari bahan beludru dipadukan dengan kain jarik motif batik. Untuk para bangsawan motif batik yang digunakan adalah motif Parang Rusak Barong. 


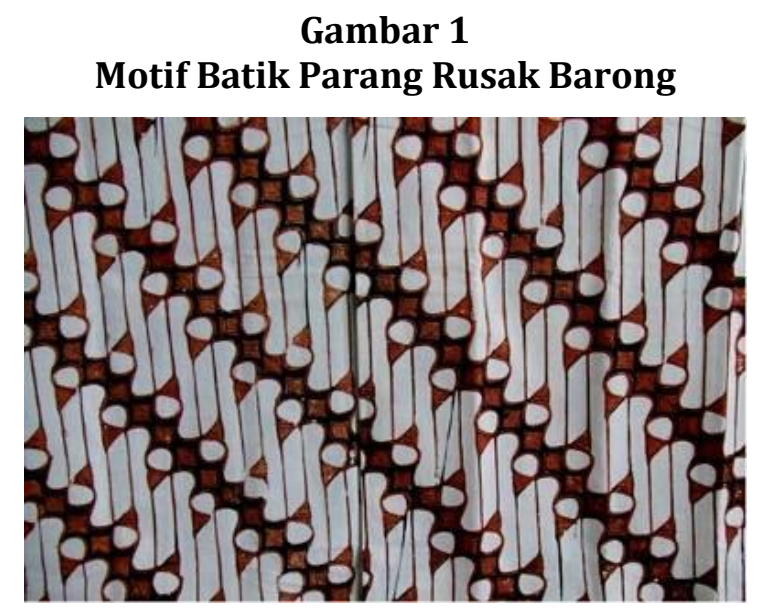

Sumber:

https://www.museumbatik.com/artikel/20 15/05/8/Makna-Filosofi-dan-cerita-diBalik-Berbagai-Motif-Batik---seriParang.html

Gambar 1 adalah motif batik Parang Rusak Barong. Motif batik tersebut hanya boleh digunakan oleh para bangsawan bumiputra. Ide membuat motif ini datang dari Sultan Agung Hanyakrakusuma. Dia ingin menyatakan pengalaman jiwanya sebagai seorang raja dengan segala tugas dan kewajibannya serta sebagai seorang manusia yang tidak berdaya di hadapan Tuhan Yang Maha Esa.

Sumber berikutnya adalah majalah. Dalam artikel ini majalah yang diulas adalah majalah Pedoman Istri dan Doenia Kita. Majalah Pedoman Istri digagas oleh Rangkajo Chailan Sjamsoe Datoe Toemenggoeng. Pedoman Istri terbit di Batavia tahun 1932, kantor pusatnya berada di Eijkmanpark. Dalam tiap terbitannya, majalah tersebut menggunakan bahasa melayu. Oleh karena Rangkajo Chailan Sjamsoe menggagas pula organisasi Persatoean Istri Pegawai Bestuur, maka isi berita majalah tersebut pun didominasi oleh berita seputar perkumpulan tersebut.

\section{Gambar 2 \\ Model Kebaya Kutubaru untuk Hari Raya}

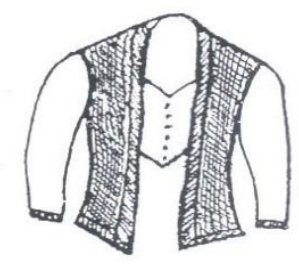

Sumber: Pedoman Istri No. 1, 1 Januari 1938
Gambar 2 merupakan satu di antara beberapa model kebaya yang dimuat dalam Majalan Pedoman Istri pada Rubrik Mode. Dalam artikel tersebut dinyatakan bahwa sebaiknya kebaya dibuat dari bahan lurik berwarna hijau tua. Bagian tangan dibuat dari kain lain yang cocok dan memiliki warna senada lurik. Bagian dada disebut kutubaru. Bagian kutubaru dapat menggunakan kain satin, crêpe, marocain, atau charmeuse, sebaiknya dihiasi pula dengan motif. Motif yang digunakan menggunakan kain yang pemilihannya diserahkan kepada selera masingmasing perempuan. Motif itu disulam dengan gambar bunga atau daun, bisa juga ditambah dengan renda atau lamee.

Majalan Doenia Kita merupakan majalah yang terbit pada November 1937 di Batavia. Penggagas majalah ini adalah seorang tokoh perempuan terkemuka bernama Alimah Latip. Majalah Doenia Kita mengusung tema kemajuan perempuan dari sudut pandang barat dan timur karena dimotori oleh perempuan-perempuan terpelajar yang juga tercatat sebagai anggota Organisasi Istri Indonesia. Sehingga tulisan di dalam majalah tersebut menyiratkan pemikiran yang sama dengan Organisasi Istri Indonesia.

Dalam Majalah Doenia Kita terdapat Rubrik Mode dimana rubric tersebut berisi pengetahuan tentang model pakaian perempuan. Model pakaian perempuan dalam majalah tersebut dibagi berdasarkan waktu pemakaian (pagi, siang, sore, dan malam).

\section{Gambar 3 \\ Model Kebaya untuk Digunakan pada Sore Hari}

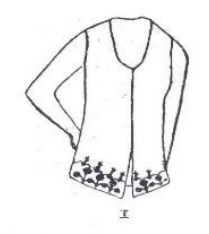

\section{Sumber: Majalah Doenia Kita, no. 5 th. 1, Maart 1938}

Kebaya pada gambar 3 merupakan satu di antara beberapa contoh model kebaya yang digunakan perempuan berdasarkan waktu pemakaian. Kebaya tersebut dibuat dari crêpe georgette warna biji gandaria (lilac). Di bagian bawah dihiasi hiasan dari beludru dan chiffon warna ungu. Sekeliling badan, leher, dan tangan 
dihiasi dengan potongan warna ungu dan kancing tangan berwana senada.

Selain memuat aturan berpakaian berdasarkan waktu pemakaian, dicantumkan pula aturan berpakaian menurut tempat dan situasi/keadaan. Misalnya, pakaian untuk acara pesta dan kematian tentu saja berbeda. Jika pada acara pesta perempuan disarankan menggunakan pakaian yang indah dan mewah agar kelihatan menarik, misalnya menggunakan bahan kain sutera berwarna cerah dengan berbagai motif. Lain halnya jika menghadiri acara kematian.

Berdasarkan artikel dalam Majalah Doenia Kita edisi No. 11, September 1938 halaman 6-7 dinyatakan bahwa orang Eropa menggunakan warna hitam dan orang Tionghoa menggunakan warna putih ketika menghadiri acara kematian. Hal tersebut sebagai cara untuk menyatakan kesedihan mereka. Namun, tidak demikian halnya bagi bumiputra. Pada masa itu, tidak ada pakaian khusus yang digunakan oleh bumiputra untuk menghadiri acara kematian seseorang. Artikel tersebut menyebutkan, bahwa kamu bumiputra tidak perlu meniru orang Eropa atau orang Tionghoa. Pakaian yang digunakan oleh bumiputra untuk menghadiri acara kematian adalah pakain yang pantas dan dapat menunjukkan empati dan rasa duka cita kepada keluarga.

Dalam Majalah Doenia Kita terdapat pula pakaian berdasarkan status perempuan (lajang atau menikah).

\section{Gambar 4 \\ Pakaian untuk Perempuan Lajang}

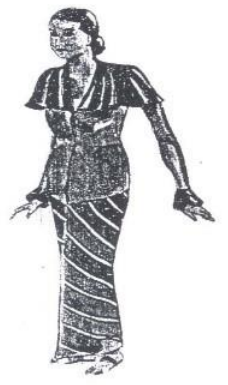

Sumber: Doenia Kita, no. 11 th. 1, September 1938

Gambar 4 merupakan gambar sebuah kebaya untuk perempuan lajang. Potongannya membentuk tubuh sehingga cocok digunakan untuk perempuan yang bertubuh langsing. Kebaya ini dibuat dari sutra berwarna blau muda yang tidak berkilat, sedangkan kraag dan manchet dibuat dari sutra berkilat yang berwarna blau tua. Kain panjang yang dipakai bermotif lereng berwarna kuning muda mencolok.

\section{Simpulan}

Sebagaimana yang diungkapkan oleh Bapak Sejarawan asal Jerman, Leopold von Ranke, pada abad ke-19 bahwa no document, no history. Oleh karenanya, sumber dalam kajian sejarah mempunyai kedudukan yang paling tinggi. Artinya, ketika seseorang bermaksud menulis karya sejarah, maka yang pertama harus ditelusuri adalah sumber.

Berkait dengan sumber tentang sejarah pakaian pada masa Pemerintahan Hindia Belanda, dapat kita lihat bahwa sebelum abad ke20 Pemerintah Hindia Belanda sangat berkepentingan mengatur tata cara berpakaian para bupati. Hal itu disebabkan oleh dalam struktur pemerintahan bumiputra kala itu, bupati menempati posisi paling tinggi, rakyat menganggap bahwa bupati sebagai representasi seorang raja-dewa. Sehingga hubungan antara rakyat dan bupati adalah hubungan kawulagusti. Pemerintah Hindia Belanda membuat aturan berpakaian untuk menarik simpati rakyat agar patuh pada perintah bupati sebagai pegawai pemerintah kolonial.

Memasuki abad ke-20, terutama ketika perempuan bumiputra mulai diizinkan untuk menempuh pendidikan di sekolah Eropa untuk bumiputra, muncullah kesadaran di kalangan perempuan bumiputra. Kesadaran tersebut meliputi kesadaran berpikir, berperilaku, dan berpenampilan. Sehingga munculah gagasan mendirikan organisasi dan menerbitkan majalah sebagai corong perjuangan mereka. Hal itu juga yang menyebabkan pada abad ke-19 belum ditemukan sumber tentang ragam pakaian perempuan.

\section{Daftar Pustaka}

Depdiknas. (2008). Kamus Besar Bahasa Indonesia.

Garraghan, G. J. (1957). A Guide to Historical Method.

Gottschalk, L. (1975). Mengerti Sejarah.

Hardjasaputra, S. A. (1985). Bupati-Bupati di Djawa; Peran Sosial Mereka pada Abad Ke19.

Model Kebaya Kutubaru untuk Hari Raya. (1938). Pedoman Istri. 
Model Kebaya untuk digunakan pada sore hari. (1938). Doenia Kita.

Motif Batik Parang Rusak Barong. (2015). https://www.museumbatik.com/artikel/2 015/05/8/Makna-Filosofi-dan-cerita-diBalik-Berbagai-Motif-Batik---serParang.html

Nordholt, H. S. (ed). (1997). Outward Appearances; Trend, Identitas, dan Kepentingan.

Reglement op de Verplichtingen, Titels en Rangen der Regenten op het Eiland Java. (1926).
Renier, G. J. (1997). Metode dan Manfaat Ilmu Sejarah.

Staatsblad tentang Pakaian Dinas Pegawai Pribumi. (1870).

Staatsblad tentang Resolusi dari Gubernur Jenderal dalam Dewan Tanggal 9 Mei 1820 No. 6 dimana dikukuhkan Menjadi Suatu Peraturan Mengenai Kewajiban dan Tugas, Pangkat dan Gelar para Bupati di Pulau Jawa. (1820).

Zakaria, Mumuh Muhsin. (2012). Bibliografi Sejarah Kesehatan Pada Masa Pemerintahan Hindia Belanda. Paramita, Vol. 22 No. 2. 